servation suggests that $\alpha$-MSH-treated mice are easily excitable under the stimulus condition of crowding as compared to isolation.

Acknowledgement: The authors wish to thank Mr. Michimasa Ohi for excellent technical assistance.

\title{
REFERENCES
}

1) Sakamoto, A.: Nature 211, 1370 (1966); 2) Sakamoto, A. and Prasad, K.N.: Protein and Polypeptide Hormones, Proc. Int. Symp. 1968, Edited by Margoulies, M., p. 503, Excerpta Med. Found., Amsterdam (1969); 3) Yajima, H., Kawasaki, K., OKada, Y., Minami, H., Kubo, K. and Yamashita, I.: Chem. Pharm. Bull. 16, 919 (1968); 4) Yajima, H. and KawaSAKI, K.: Chem. Pharm. Bull. 16, 1379 (1968); 5) Lerner, A.B. AND MCGUIRE, J.S.: Nature 189, 176:(1961)

\section{SKELETAL CHANGES INDUCED BY DOPA DECARBOXYLASE INHIBITOR IN RATS}

\author{
Chikako TANAKA*, Seisuke TANAKA**, Yoshinori ITOKAWA*** \\ and Shuji TAKAORI* \\ Department of Pharmacology*, Department of Orthopaedic Surgery** \\ and Department of Hygiene***, Faculty of Medicine, \\ Kyoto University, Sakyo-ku, Kyoto, Japan \\ Accepted 16 October 1972
}

Inhibition of extracerebral decarboxylase activity by N-(DL-seryl)-N-(2, 3, 4-trihydroxybenzyl)-hydrazine (Ro 4-4602, Hoffmann-La Roche) has been reported to produce a marked enhancement of brain dopamine content following administration of L-dopa (1). Ro 4-4602 has been, therefore, considered for use as a supplementary drug in the dopa therapy of Parkinsonian patients. In the present experiments using rats, skeletal changes and biochemical manifestation in bone and blood induced by Ro 4-4602 were studied.

Male Wistar strain rats weighing approx. $250 \mathrm{~g}$ (3 months old) at the beginning of experiment were used. These were housed in separate cages at $22-24^{\circ} \mathrm{C}$ under a constant day-night rhythm. The animals were fed a commercial diet (Japan CLEA Co., CA-1) and drinking water ad libitum for 3 days, then separated into 3 groups of 10 . The first group served as control. The second group was given the standard diet plus $0.1 \%$ Ro $4-4602$ ( $0.1 \%$ group) and the last group was maintained on the standard diet plus $1.0 \%$ Ro 4-4602 (1.0\% group). Body weight, food intake and drug dosage were measured every 3 days.

Throughout the experiments, daily intake of Ro $4-4602$ in the $0.1 \%$ and $1.0 \%$ groups ranged from 58 to $71 \mathrm{mg} / \mathrm{kg}$ and 396 to $613 \mathrm{mg} / \mathrm{kg}$, respectively. Growth curve in the 
TABLE 1. Radiographic findings in the knee joint and spine of rats.

\begin{tabular}{|c|c|c|c|c|c|c|c|c|}
\hline & & \multirow{2}{*}{$\begin{array}{c}\text { Control } \\
2-6\end{array}$} & \multicolumn{3}{|c|}{$0.1 \%$ Ro $4-4602$} & \multicolumn{3}{|c|}{$1.0 \%$ Ro $4-4602$} \\
\hline & & & 2 & 4 & 6 & 2 & 4 & 6 weeks \\
\hline \multirow{5}{*}{ Knee joint } & $\begin{array}{l}\text { Widening of epiphyseal cartilage } \\
\text { plate }\end{array}$ & - & \pm & + & + & $H$ & $H$ & $H$ \\
\hline & Epiphyseal slipping & - & - & - & \pm & + & $H$ & H \\
\hline & Metaphyseal cupping or bowing & - & - & - & \pm & + & $H$ & $H$ \\
\hline & Periostal new bone formation & - & - & - & - & \pm & $H$ & $H$ \\
\hline & Loss of bone density & - & \pm & \pm & \pm & \pm & + & $H$ \\
\hline \multirow{3}{*}{ Spine } & $\begin{array}{l}\text { Flexion deformity of atlanto- } \\
\text { occipital joint }\end{array}$ & - & \pm & + & + & + & + & + \\
\hline & $\begin{array}{l}\text { Abnormal curvature in dorsal } \\
\text { spine }\end{array}$ & - & - & \pm & + & \pm & + & + \\
\hline & Loss of bone density & - & - & - & \pm & \pm & + & + \\
\hline
\end{tabular}

- : No change, $\pm:$ Slight, $+:$ Moderate, $+:$ Marked

$0.1 \%$ group was slightly depressed as compared with that of control. In the $1.0 \%$ group, body weight was reduced by approx. $10 \%$ during the first 4 weeks. Knee and hip joint contracture and deformities of spine were observed from the 6th week in the $0.1 \%$ group and the 2 nd week in the $1.0 \%$ group. For radiographic examination of the entire body, the animals were anesthetized with intraperitoneal injection of pentobarbital sodium (35 $\mathrm{mg} / \mathrm{kg}$ ). As shown in Table 1, main findings at the 2 nd week in the $1.0 \%$ group were widening of epiphyseal proximal cartilage plate of tibia, epiphyseal slipping of femur and tibia, cupping and bowing of proximal metaphysis of tibia and flexion contracture of atlanto-occipital joint. At the 4th week, joint contracture, epiphyseal slipping and metaphyseal cupping and bowing were markedly exaggerated, and in addition, loss of bone density and periostal new bone formation were observed in the femur and tibia. Abnormal curvature in the dorsal spine was also seen. These joint contracture and radiographic findings in the $0.1 \%$ group were less than those in the $1.0 \%$ group.

TABLE 2. Ca, Mg and $\mathbf{P}$ levels in bone and blood of rats treated with Ro 4-4602 for 4 weeks.

\begin{tabular}{clccc}
\hline & & $\begin{array}{c}\mathrm{Ca} \\
(\mathrm{g} / 100 \mathrm{~g} \text { d.w. })\end{array}$ & $\begin{array}{c}\mathbf{M g} \\
(\mathrm{mg} / 100 \mathrm{~g} \text { d.w. })\end{array}$ & $\begin{array}{c}\mathbf{P} \\
(\mathrm{g} / 100 \mathrm{~g} \text { d.w. })\end{array}$ \\
\hline \multirow{3}{*}{ Femur } & Control & $26.35 \pm 0.83$ & $0.47 \pm 0.02$ & $14.43 \pm 0.28$ \\
& $0.1 \%$ group & $23.60 \pm 1.63$ & $0.45 \pm 0.01$ & $13.32 \pm 0.52$ \\
& $1.0 \%$ group & $18.58 \pm 0.72^{*}$ & $0.38 \pm 0.03^{*}$ & $9.51 \pm 0.59 *$ \\
\hline \multirow{3}{*}{ Blood } & & $(\mathrm{g} / \mathrm{dl})$ & $(\mathrm{mg} / \mathrm{dl})$ & $(\mathrm{g} / \mathrm{dl})$ \\
& Control & $5.12 \pm 0.24$ & $2.93 \pm 0.33$ & $0.037 \pm 0.001$ \\
& $0.1 \%$ group & $5.64 \pm 0.20$ & $2.69 \pm 0.22$ & $0.031 \pm 0.004$ \\
& $1.0 \%$ group & $4.61 \pm 0.31$ & $2.99 \pm 0.21$ & $0.022 \pm 0.002^{*}$ \\
\hline
\end{tabular}

Each value represents mean \pm standard error $(n=5)$.

* : Significant decrease as compared with respective control ; $\mathbf{P}<0.05$ (Student's t-test). 
At the end of the 4th week, 5 animals from each group were sacrificed. Blood was collected from the abdominal aorta and centrifuged. Femurs were removed for mineral assay. Amounts of calcium $(\mathrm{Ca})$ and magnesium $(\mathrm{Mg})$ in blood and bone were determined using an atomic absorption spectrophotometer (MAF-1, Shimazu) following wet oxidations of the samples (2). Total phosphorus (P) content was determined by the method of Chen et al. (3). Table 2 shows the mineral levels in the control and drug-treated animals. In the $1.0 \%$ group, $\mathrm{Ca}, \mathrm{Mg}$ and $\mathrm{P}$ levels in the femur were significantly lowered as compared with respective control. Lowering of $\mathbf{P}$ level in the blood was also observed in the $1.0 \%$ group, without any specific changes in blood levels of $\mathrm{Ca}$ and $\mathrm{Mg}$.

Urinalysis was performed during 6 weeks of the feeding. Urine volume for $5 \mathrm{hr}$ in the $1.0 \%$ group increased to approx. twice of that of the control. The drug had no effect on $\mathrm{pH}$ and glucose in the urine; however, a two-dimensional paper chromatography of the urine demonstrated an abnormal generalized aminoaciduria, with a particularly high excretion of phenylalanine, tyrosine, histidine, methionine and threonine in the drugtreated animals.

The present findings indicate that inhibition of decarboxylase activity induced by Ro 4-4602 produces an amino acid imbalance, based on impaired tyrosine metabolism in rats. Abnormal accumulation of amino acids in the kidney could have induced multiple renal tubular defects such as generalized aminoaciduria and abnormal loss of phosphorus. This concept is supported by the fact that the findings described herein resemble rickets in concomitance with congenital amino acid metabolic disorders $(4,5)$.

\section{REFERENCES}

1) Bartholoni, G., Bates, H.M., Burkard, W.P. and Pletscher, A.: Nature, Lond. 215, 852 (1967); 2) Alcock, N.W. AND Maclentyre, I.: Methods of Biochemical Analysis, Edited by Glick, D., Interscience Publ., New York (1966); 3) Chen, P.S., Toribara, Jr., T.Y. AND Warner, H.: Anal. Chem. 28, 1756 (1956); 4) De Toni, G.: Ann. Paediat. 187, 42 (1956);

5) Gentz, J., Jagenburg, R. and Zetterstrom, R.: J. Pediat. 66, 670 (1965) 